LIU Wei, LIU Xing

\title{
Auditor switching, earnings manipulation and auditor independence: Evidence from A-share listed companies in China
}

\author{
(C) Higher Education Press and Springer-Verlag 2008
}

\begin{abstract}
Based on data from Chinese A-share listed companies between 1999 and 2004, this paper examines the causes of auditor switching and its effects on the independence of successive auditors from the perspective of earnings manipulation. Results show that: (1) listed companies manipulate their earnings through replacing their auditor and the successive auditor fails to exercise necessary prudence; (2) for companies reporting profit in the year of auditor change, the formerly low discretionary accruals usually increase significantly after the switch mostly resulting from assets devaluation and adjustments to non-recurring items; (3) In contrast, for companies reporting losses in the year of auditor change, they take a "big bath" to adjust lower earnings of the same year. These findings indicate that auditor change is related to the conservatism of predecessor auditors and it damages the independence of successive auditors.
\end{abstract}

Keywords auditor switching, earnings manipulation, auditor independence, discretionary accruals

摘要 以 1999-2004 年间我国 A 股上市公司为样本, 对审计师变更、盈余操纵与审 计师独立性之间的关系进行实证检验, 结果发现: (1) 上市公司能够通过更换审计 师达到操纵盈余的目的, 同时后任审计师对此并未保持应有的谨慎; (2) 变更审计

Translated and revised from Guanli shijie 管理世界(Management World), 2007, (9): 129-135

LIU Wei $(\bowtie)$

School of Business, Shantou University, Shantou 515063, China

E-mail: wliu@stu.edu.cn

LIU Xing

College of Economics and Business Administration, Chongqing University, Chongqing 400030, China

E-mail: liuxing@cqu.edu.cn 
师当年报告盈利的公司, 其操控性应计利润在变更前相对较低, 而变更后得以显著 增长, 且增长主要来自于对资产减值准备、非经常性损益项目的利润调节; (3) 与 此相反, 变更审计师当年报告亏损的公司, 在变更当年存在调低收益的 “清洗” 活 动。上述结果表明: 审计师变更与前任审计师的稳健性有关, 且这种变更行为损害 了后任审计师的独立性。

关键词 审计师变更, 盈余操纵, 审计师独立性, 操控性应计利润

\section{Introduction}

In recent years, frequent auditor switching has drawn increasing attention from both government regulators and academic research. In 2003, the Chinese Institute of Certified Public Accountants (CICPA) issued the Specific Standard for Independent Auditing (No.28) to highlight the communication between predecessor and successor auditors, as well as to remind successor auditors of potential risks of auditor switching. Soon after, CICPA listed the auditor switching problem as one of its supervisory priorities of the year (refer to Code No. 9, 2004). As pointed out by CICPA, vicious auditor switching may induce avoidance of unfavorable auditor opinions and loss of auditor independence, and impair the development of China's capital market accordingly.

Overseas studies on auditor switching can be traced back to 1960s. Since then, western researchers have made substantial progresses in studying motives behind auditor switching and its economic consequences, providing important theoretical guidance and empirical evidences to government departments concerned. China's capital market, however, has not been established until the early 1990s. In comparison with developed countries, the market environment, corporate governance, and the auditors' professional standards in the Chinese capital market are far from being mature. Under such circumstances, facing the serious problem of auditor switching, how can Chinese auditors exercise necessary prudence and remain independent? Settlement of these problems is of critical importance to the future development of China's capital market. Most of Chinese researchers, when studying the above issues, focused on the motives behind listed companies' auditor switching behaviors and consequent economic results (e.g. Li et al., 2001; Yang and $\mathrm{Xu}, 2004$, Wu et al., 2005). Only few studies attempted to explore into auditor switch behaviors from the perspective of earnings manipulation (Chen and Zhang, 2004). Although Chinese scholars have achieved a great deal in the understanding of auditor switching motives, their conclusions concerning whether auditor changes will impair the independence of auditors are always inconsistent, or even contradicting, with one another. Why is this? In the following sections, we will first analyze causes of the 
inconsistency in conclusions. Then based on our discussion, we will further probe into motives behind auditor switching and the effect of auditor switching on auditor independence.

To begin with, a majority of extant studies on motives and influences of auditor switching were conducted from the perspective of audit opinion improvement. Yet this leaves the fact that some listed companies with standard audit opinion also change their auditors unexplained. As a matter of fact, auditors vary in their degrees of conservatism for earnings manipulation. Thus there is a possibility that listed companies may replace more conservative auditor with less prudent one for the purpose of earnings manipulation. In viewing of this possibility, the present paper studies motives behind auditor switching and its consequent economic results from the standpoint of earnings manipulation. The results revealed that listed companies are able to manipulate earnings by means of auditor switching. Furthermore, comparisons of audit opinions by both predecessor auditors and successor auditors showed that successor auditors tend to fail to exercise necessary prudence against this type of earnings-manipulation-oriented switches. Our analysis also revealed that listed companies received modified audit opinions are likely to change their auditors, aiming at audit opinion shopping. The results partially explained the research conclusion inconsistency in auditor switching literature: diverse perspectives lead to inconsistent conclusions.

Secondly, different sampling and test methods may also lead to the above inconsistency in conclusions. For instance, a listed company may either "increase" earnings to make its performance look good, or "reduce" earnings to take a "big bath". We took into consideration both possibilities in the present article and, based on this, explored into the relation between auditor switching and earnings manipulation and its effect on auditor independence. The results showed that profit-making companies and loss-suffering companies differ in their purposes of auditor switching. The former changes its auditor to increase its earnings, while the latter for an earnings-reducing "big bath". In studying earnings manipulation in the Chinese context, most of extant researches failed to distinguish between profit-making companies and loss-suffering companies, resulting in widely discrepant conclusions of auditor switching (as an example, we analyzed in great details Chen's article in sections that followed).

Finally, the said inconsistent viewpoints on the effect of auditor switching on auditor independence may also result from different variable design methods. To solve the problem, we adopted the Jones Model (1991) and it modified model to estimate discretionary accruals, as so to measure possible earnings manipulation behaviors of auditor-switching companies. We also investigated the accrual items in companies committed earnings manipulation to know the specific 
earning-manipulating methods each company used. To ensure the reliability of our conclusions, a number of stability tests were conducted under various circumstances, such as by applying different accounting standards and by adopting different sampling criteria, etc.

In summary, our findings showed that auditor switching affects negatively auditor independence, thus providing empirical evidences for government regulators in charging of auditor switching supervision. Secondly, from the perspective of earnings manipulation, we explained the phenomenon of frequently switching auditors in China's capital market, which is of supplementary significance to the study on auditor switch in developing countries. Thirdly, by comparing the quality of auditing services provided by different auditors, our study provided preliminary supports for application of the Auditor Differentiation theory under the Chinese context. Finally, we analyzed, in the present article, the constraints outside auditor exert over listed companies' earnings management behaviors and specific methods adopted by listed companies for earning manipulation, thus contributing to the literature of earnings management studies.

The remainder of this paper proceeds as follows: in section 2, we review briefly the research background and develop our hypotheses. Research design and sample choice are presented in Section 3. In Section 4 and 5, we analyze the empirical results of our study and probe into the specific approaches of earnings manipulation listed companies adopt. Conclusion and limitation are presented in the last section.

\section{Background and hypotheses}

\subsection{Background}

Evidences have indicated that there are serious earnings manipulation problems among Chinese listed companies. In most cases, listed companies manipulate their earnings to cater for or to elude government regulation (Haw et al., 1998; $\mathrm{Lu}$, 1999; Cheung et al., 2000), which is closely linked with the uniqueness of China's institutional background. Through the whole process of China's economic system transition, government regulation remains pervasive at every phase of China's capital market development. Great emphasis has been laid on listed companies' excellent performance. For example, the Codes prescribe that a firm will receive "Special Treatment"(ST) from the security exchange in case it has made a loss for two consecutive years, and will receive "Particular Treatment"(PT) or face "delisting" if it has made a loss for three consecutive years and fails to reverse the situation before the deadline. For companies 
qualified for listing, they must meet the minimum level of earnings in order to realize the refinancing objective. Under this unique system arrangement, avoiding delisting or striving for refinancing have become an important motivation for earnings management of listed companies. In view of the rigidity of supervising regulation, the best strategy for listed companies to manipulate their earnings is to make the level of earnings to arrive at the threshold of the regulation. In this way, they can gain the greatest margin profit or the least margin cost (hypothesizing that they must pay to manipulate earnings). Therefore, for the sake of avoiding ST or PT or obtaining the qualification of refinancing, listed companies aim to enhance the current earnings to make a profit or to arrive at the threshold of refinancing policy. Meanwhile, for those listed companies impossible to make a profit, they will enlarge the current loss for offering conveniences to turn loss into gain in the next year.

Evidences to prove the above indication has accumulated. Haw et al. (1998), Sun and Wang(1999), Chen et al.(2000) examined the frequency distribution of returns on equity(ROE) of listed companies, and discovered that on the right side of the threshold of seasoned equity offering( $\mathrm{ROE}$ is equal to 10 per cent), listed companies tend to concentrate, representing that they are likely to manipulate their earnings in order to meet the requirements of seasoned equity offering. In addition, Lu(1999) and Cheung and Dai(2004) and Dai et al.(2005) found that for avoiding being "ST" or "PT", listed firms are prone to take "big-bath" to significantly enlarge their loss in order to turn loss into gain in next year.

In an efficient auditor market, auditors are able to distinguish and report clients' earnings manipulation(Zhang and Liu, 2002; Li et al., 2004). The reason is that auditors have an incentive to protect themselves against potential damages arising from clients' earnings manipulation through their audit opinions. When the auditors hold opposite opinions to the client's earnings manipulation and even draw modified opinions, disagreement between the auditor and the client occurs. As a result, the client has an incentive to dismiss the incumbent auditor in hopes of finding a more indiscreet successor. For example, analytical work by De Fond et al. (2000) concluded that top ten auditors lose market share subsequent to the adoption of the new auditing standards in China and that the listed firms in China have propensity to elude the high audit quality, supposing that audit quality is better in the large auditors than small ones(DeAngelo, 1981) and that the new standards help to improve the auditor independence as a whole. For that, auditor switches and their impact to the independence of successor auditors have received high attention from government regulators and academic researchers alike.

\subsection{Literature review and hypothesis development}

Few empirical evidences have been founded to support the worry that auditor 
changes are closely associated with the opinion shopping and bring a threat to the independence of auditors. Although some literature has reported that auditor switches are significantly associated with the modified opinion in the last year(Geng and Yang, 2001; Li et al., 2001), there are inconsistent evidences regarding the question whether the firms changing auditors have successfully shopped opinions. For example, following the research methods of Lennox(2000), Yang and Xu(2004) examined the impact of auditor changes on the independence of the auditors and founded that the listed companies can achieve their objects of shopping opinions to some extent by changing auditors. On the contrary, analysis work by Wu and Tan(2005) showed that the listed firms could not significantly improve auditing opinions by changing auditors, indicating that the firms' conducts are futile under the motivation to gain the attractive objectives of opinions shopping by changing auditors.

The main reason for the above inconsistent evidences is, though we are able to observe types of the audit opinions issued to the listed firms before and after auditor changes, it is important to compare audit opinions issued by the auditors being changed with the opinions would be issued if the auditor had not been changed. But, much to our dismay, the latter case can never be observed. Accordingly, it is irrational to adopt the audit opinion before auditor changes as a proxy to reflect whether the listed firms have motives for opinion shopping or succeed in doing so. Following the same research methods of Lennox (2000), Yang and $\mathrm{Xu}(2004)$, $\mathrm{Wu}$ and Tan (2005) both designed, independently, an auditing report model to stimulate the said unobservable event (namely the very types of audit opinions when the sample firms do not change their auditors) in order to examine the occurrence of opinions shopping. However, the reliability of their conclusions was largely depended on the accuracy of the auditing report model and different designs of the above two models herein finally led to two contradictive conclusions.

Only few studies attempted to interpret auditor switches from the viewpoints of clients' earnings manipulation. Drawing on the research of De Fond and Subramanyam(1998), Chen and Zhang (2004) pointed out that some auditors prefer conservative accounting choices for fear of possible litigation risks, which motivate their clients (e.g. listed companies) to dismiss the incumbent auditors. By analyzing the sample firms that changed auditors during the four-year period from 1999 to 2002, they found that auditor switches in these companies were usually triggered by the more conservative accounting process method of predecessor auditors, yet the independence of successor auditors did not decline accordingly. Chen and Zhang, however, ignored that, under the unique Chinese institutional background, there were divergent motives and directions for listed companies' earnings manipulation behaviors. As mentioned earlier, 
profit-making companies and loss-suffering companies differ in their purposes of auditor switch. They may either increase their earnings for performance embellishment (in a positive direction), or decrease their earnings for "big bath" (in a negative direction). Fail to take that point into account might lead to inaccuracy in research conclusions (further analyses are provided in 4.2).

Drawing on the above rationale, we took into consideration of different directions of earnings manipulation and accordingly explored into motives behind auditor switch and its effect on the independence of successive auditors from the perspective of earning manipulation. We conjectured that auditors vary in their attitudes toward earning manipulation, which in turn lead to cases of auditor switch ${ }^{1}$. To illustrate, when a listed firm assumes that its incumbent auditor is more conservative than average, it will dismiss the auditor in hopes of obtaining a less conservative successor. If the behavior of listed firm is rational, we can expect that prominent changes occur in the discretionary accruals of the listed firms before and after auditor changes. Second, the prior researches have indicated that there are mainly two situations in listed firms' earnings manipulation: either to enhance the current earnings to make a "profit", or to take big bath to enlarge the current loss(e.g. Haw et al., 1998; Lu, 1999).In other words, profit-making companies and loss-suffering companies may differ in the directions of earnings manipulation. Hence, we used in the present article whether a listed company reported profit or loss in the year of auditor change as an index of its earnings manipulation direction. More specifically, to the firms reporting profit in the year of auditor change, their discretionary accruals tend to increase dramatically after the auditor switch. On the contrary, firms reporting loss in the year of auditor change are prone to take big-bath to decrease their income after auditor changes, as represented by notably decline in discretionary accruals.

With the above analyses, we developed the following hypothesis, namely firms reporting profit in the year of auditor change would significantly increase their discretionary accruals after auditor switch, while firms reporting loss in the year of auditor change would remarkably decrease their discretionary accruals after auditor switch.

\section{Research design}

\subsection{Estimation of discretionary accruals}

Considering that most Chinese companies are newly-listed ones and there lacks

${ }^{1}$ Consistent with our conjecture, both Zhang (Zhang, et al. 2002) and Cai (Cai et al., 2005) discovered that different auditors had different preferences to the clients' earnings manipulation. 
enough time serial data to guarantee the validity of parameter estimation, the cross-sectional Jones Model and its modified model were adopted to estimate discretionary accruals.

(1) Basic Jones Model

$$
N D A_{i, t}=\beta_{1}\left(1 / A_{i, t-1}\right)+\beta_{2}\left(\Delta R E V_{i, t} / A_{i, t-1}\right)+\beta_{3}\left(P P E_{i, t} / A_{i, t-1}\right)
$$

Among the abbreviations, $N D A_{i, t}$ stands for the non-discretionary accruals of listed company $i$ after adjustment of total assets at the end of Time $t-1 ; \Delta R E V_{i, t}$ is the prime operating revenue at Time $t$ minus prime operating revenue at Time $t-1 ; P P E_{i, t}$ represents original value of fixed assets; $A_{i, t-1}$ is total assets at the end of Time $t-1$. Estimation of parameters $\beta_{1}, \beta_{2}, \beta_{3}$ all used cross-sectional data. By regressing sample companies in the same industry and of the same year, we got the following two equations.

$$
\begin{aligned}
& T A_{i, t} / A_{i, t-1}=b_{1}\left(1 / A_{i, t-1}\right)+b_{2}\left(\Delta R E V_{i, t} / A_{i, t-1}\right)+b_{3}\left(P P E_{i, t} / A_{i, t-1}\right)+\varepsilon_{i, t} \\
& T A_{i, t}=N I_{i, t}-C F O_{i, t}
\end{aligned}
$$

In Model (2), $T A_{i, t}, N I_{i, t}, C F O_{i, t}$ represent total accruals, net profit, and net cash flow from operating at Time $t$, respectively. $D A_{i, t}$ (discretionary accruals) equals total accruals minus non-discretionary accruals, as below.

$$
D A_{i, t}=T A_{i, t} / A_{i, t-1}-N D A_{i, t}
$$

(2) Modified Jones Model

$$
N D A_{i, t}=\beta_{1}\left(1 / A_{i, t-1}\right)+\beta_{2}\left[\left(\Delta R E V_{i, t}-\Delta R E C_{i, t}\right) / A_{i, t-1}\right]+\beta_{3}\left(P P E_{i, t} / A_{i, t-1}\right)
$$

In equation (5), $\triangle R E C_{i, t}$ meant the difference between the accounts receivable at Time $t$ and Time $t-1$. The definitions of other variables were the same as in equation (1). One need to notice that values of parameter $\beta_{1}, \beta_{2}, \beta_{3}$ were estimated from the basic Jones Model, that is, estimate values of equation (2) and (3). The only difference between the two is that in the basic model, non-discretionary accruals is a function of sales revenue change and capital expenditure, while in the modified model, non-discretionary accruals associate only with cash sales(instead of sales revenue). Thus in the modified model, the change value of accounts receivable should be deducted from changes in sales revenue. We then calculated discretionary accruals with Equation (4).

\subsection{Sample selection and data resources}

Before 1999, cases of auditor switch were quite rare $^{2}$. We therefore chose all

\footnotetext{
${ }^{2}$ Geng and Yang(2001) found that only 2 cases of auditor switch in 1995, 10 in 1996, 23 in 1997, and 35 in 1998.
} 
A-share listed companies from 1999-2004 as initial samples. All data used in the present article were from China Stock Market Financial Database (CSMAR). After deleting involuntary auditor switch cases (such as predecessor auditor quit his/her job, merged with other auditing companies, or failed to pass annual qualification inspections, etc), the initial samples reduced to 486 annual company observation points. For each auditor-changed company, we collected data of all non-auditor-switching companies from the same industry (for industries in the Code of Industry, we chose the first number of the code, While for industries belong to category $\mathrm{C}$, the first two numbers ${ }^{3}$ ) at the same year as control samples. In addition, we deleted from samples the following types of companies:

(1) Companies with incomplete data or with data incomplete for three consecutive years.

(2) Financial companies (coded I in the Code of Industry) and broadcasting \& culture companies (code L) owing to the scarcity of samples.

(3) Companies issued both $\mathrm{A}$ and $\mathrm{B}$ shares, or both $\mathrm{A}$ and $\mathrm{H}$ shares simultaneously.

(4) Companies facing insolvency threat or their ROEs fall outside the interval of $-50 \%$ and $50 \%$ as extremes. ${ }^{4}$

(5) For companies changed auditors continuously, we chose only the data of last auditor switch to avoid potential influence of consecutive auditor changes.

After the above screening, we got 283 observation points of auditor switch and 3988 observation points of non auditor switch. The total numbers of observation points were 4271 .

\section{Results and analysis}

4.1 A brief comparison between auditor-switching and non auditor-switching companies

Using the above method, we calculated the discretionary accruals of sampled listed companies in the year before auditor switch and in the year of auditor switch respectively. Then by means of sample paring, we compared

\footnotetext{
${ }^{3}$ Due to the scarcity of company numbers in industry $\mathrm{C} 2$ and $\mathrm{C} 9$, we combined these two industries as one in the present article.

${ }^{4}$ Dechow, Sloan and Sweeney (1995) pointed out that the estimated values of discretionary accruals by using the Jones model and its modified one may deviated greatly from the actual values, provided that sample companies with extreme financial performances were not deleted. We therefore eliminated companies facing insolvency threat or observation values with extreme ROEs falling outside the interval of $[-50 \%, 50 \%]$. We also tested the effect of extremes on our conclusions, as discussed below.
} 
auditor-switching companies with their non-auditor-switching counterparts (that is, companies with more or less the same total assets and from the same industry) in the same year. As shown in Table 1, one year before auditor change, the discretionary accruals (DA1 and DA2) of auditor-switching companies were significantly lower than that of non-auditor-switching companies. After the switch, however, auditor-switching companies' discretionary accruals grew dramatically. The means of DA1 and DA2 were increased by 0.009 and 0.011 respectively, the medians of DA1 and DA2 rose by another 0.004 as well, which were both significantly higher than that of non-auditor-switching companies at the 0.05 confidence level. By comparison, the discretionary accruals of non-auditor-switching companies tended to decrease, which was consistent with the implementation of new accounting standards at the time, implying that the regulation of "eight provisions for reserves" in the new accounting standards did facilitate the production of more reliable financial reports. Under such circumstance, however, the discretionary accruals of auditor-switching companies showed a tendency of increase as a whole. We could thus infer that these companies changed their more conservative predecessor auditors and successfully boosted up their earnings by adjusting discretionary accruals after auditor switch.

Table 1 A brief comparison between auditor-switching and non-auditor-switching companies (each subgroup contains 283 listed companies)

\begin{tabular}{llcccc}
\hline Time & $\begin{array}{c}\text { Samples } \\
\text { comparison }\end{array}$ & \multicolumn{2}{c}{$\begin{array}{c}\text { Discretionary accruals 1 } \\
\text { (DA1) }\end{array}$} & \multicolumn{2}{c}{$\begin{array}{c}\text { Discretionary accruals 2 } \\
\text { (DA2) }\end{array}$} \\
\cline { 3 - 6 } & & Means & Medians & Means & Medians \\
\cline { 3 - 6 } Year before the & $A S C$ & -0.012 & -0.013 & -0.012 & -0.014 \\
switch & $N A S C$ & 0.006 & 0.009 & 0.007 & 0.009 \\
& $(p$-value $)$ & $(0.031)^{* *}$ & $(0.044)^{* *}$ & $(0.021)^{* *}$ & $(0.029)^{* *}$ \\
Year of the switch & $A S C$ & -0.003 & -0.000 & -0.002 & 0.002 \\
& $N A S C$ & -0.007 & -0.003 & -0.008 & -0.002 \\
& $(p$-value $)$ & $(0.505)$ & $(0.416)$ & $(0.409)$ & $(0.342)$ \\
Discretionary & $A S C$ & 0.009 & 0.004 & 0.011 & 0.004 \\
accruals changes & $N A S C$ & -0.013 & -0.008 & -0.015 & -0.010 \\
before and after & $(p$-value) & $(0.047)^{* *}$ & $(0.043)^{* *}$ & $(0.027)^{* *}$ & $(0.023)^{* *}$ \\
the switch & & \multicolumn{3}{c}{} \\
\hline
\end{tabular}

Notes:

(1) Abbreviations ASC and NASC stands for auditor-switching companies and non-auditor-switching companies respectively.

(2) The means and medians in the table correspond with the $p$ values of the $T$ test of paired samples and of Wilcoxon signed rank test respectively. ${ }^{*}, * *, * * *$ mean the means or medians are significant at $10 \%, 5 \%, 1 \%$ levels respectively.

(3) DA1 and DA2 stand for, respectively, estimated discretionary accruals with basic Jones model and modified Jones model. 


\subsection{Relation between auditor switch and earnings manipulation}

To test our hypothesis, we divided sample companies into two sub-groups, namely profit-making companies and loss-suffering companies, in accordance with their financial reports at the year of auditor switch. We then analyzed respectively changes in discretionary accruals before and after the switch. Since the analysis results of DA1 and DA2 were identical, we presented below only the results of DA1 based on the basic Jones Model. Column A in Table 2 showed that, for companies made profit at the year of auditor switch, their discretionary accruals of the year before were significant negative and the discretionary accruals boosted up after the switch (the mean and median increased by 0.018 and 0.011 respectively, significant at the $5 \%$ level). In contrast, loss-suffering companies significantly reduced their discretionary accruals. The mean and median of the decrease range $(\triangle D A 1)$ were -0.052 (significant at the $10 \%$ level)and -0.053 (significant at the $5 \%$ level), respectively. These results were consistent with our hypothesis, implying that profit-making companies and loss-suffering companies vary in their motives for auditor switch. The former want to increase earnings, while the latter yearn for a "big bath" through auditor switch. In line with our conclusion, Huang (2002) reported that some listed companies took advantages of accounting standards changes ${ }^{5}$ and carried out "big bath charges". Lu (1999) also found that loss-suffering companies adopted accountings treatments to significantly reduce their discretionary accruals in the year of losses.

Our results were contrary to Chen and Zhang's (2004) findings. After analyzing listed companies conducted auditor switch from 1999 to 2002, Chen and Zhang found that changes in discretionary accruals after the switch were not significant statistically, they thus concluded that the independence of successive auditors were not impaired. To check this presumption, we re-tested changes in discretionary accruals before and after auditor switch during the same period, as depicted in Column B of Table 2. We found that the changes were not significant, regardless of profit-making companies or loss-suffering companies. Under such circumstance, our results were in support of Chen and Zhang's conclusion. After dividing sample companies into groups of profit-making or loss suffering, however, we found that companies making profit at the year of auditor switch distinctively boosted up their discretionary accruals, the mean and median of $\triangle D A$ were 0.023 and 0.007 respectively and both were significant at the $10 \%$ level; while companies suffering losses at the year of auditor switch remarkably

\footnotetext{
${ }^{5}$ For example, the China Accounting System for Business Enterprises (2001) requires listed companies to make provisions for four new reserves for depreciation, thus extending the number of depreciation reserves items to 8 .
} 
reduced their discretionary accruals, the mean and median of $\triangle D A$ were -0.089 and -0.054 respectively and both were highly significant at the $1 \%$ level. We thus argued that an overlook of the earning manipulation differences between profit-making companies and loss-suffering companies in Chen and Zhang's article was the main cause of this conclusion inaccuracy.

Table 2 Results of group testing on auditor-switching companies

\begin{tabular}{|c|c|c|c|c|c|c|}
\hline \multirow[b]{2}{*}{ Year } & \multirow{2}{*}{$\begin{array}{c}\text { Period } \\
\text { Grouping }\end{array}$} & \multicolumn{2}{|c|}{ A: $\quad(1999-2004)$} & \multicolumn{3}{|c|}{ B: (1999-2002) } \\
\hline & & $\begin{array}{l}\text { a. Made } \\
\text { profit at } \\
\text { the year }\end{array}$ & $\begin{array}{c}\text { b. Suffered } \\
\text { loss at the } \\
\text { year }\end{array}$ & $\begin{array}{c}\text { Total } \\
\text { samples }\end{array}$ & $\begin{array}{l}\text { a. Made } \\
\text { profit at } \\
\text { the year }\end{array}$ & $\begin{array}{c}\text { b. Suffered } \\
\text { loss at the } \\
\text { year }\end{array}$ \\
\hline Changes & $\begin{array}{c}\text { Observation } \\
\text { values }\end{array}$ & 249 & 34 & 165 & 144 & 20 \\
\hline Year before & Mean & $\begin{array}{c}-0.012^{*} \\
(0.06)\end{array}$ & $\begin{array}{l}-0.01 \\
(0.63)\end{array}$ & $\begin{array}{c}-0.013 \\
(0.14)\end{array}$ & $\begin{array}{c}-0.016^{*} \\
(0.09)\end{array}$ & $\begin{array}{l}0.009 \\
(0.64)\end{array}$ \\
\hline the Switch & Median & $\begin{array}{c}-0.014 * * * \\
(0.00)\end{array}$ & $\begin{array}{l}0.016 \\
(0.86)\end{array}$ & $\begin{array}{c}-0.011 \\
(0.16)\end{array}$ & $\begin{array}{c}-0.015^{*} \\
(0.06)\end{array}$ & $\begin{array}{l}0.028 \\
(0.38)\end{array}$ \\
\hline Year of the & Mean & $\begin{array}{l}0.006 \\
(0.34)\end{array}$ & $\begin{array}{c}-0.063 * * * \\
(0.00)\end{array}$ & $\begin{array}{c}-0.004 \\
(0.62)\end{array}$ & $\begin{array}{l}0.007 \\
(0.40)\end{array}$ & $\begin{array}{c}-0.08 * * * \\
(0.00)\end{array}$ \\
\hline switch & Median & $\begin{array}{l}0.006 \\
(0.45)\end{array}$ & $\begin{array}{c}-0.079 * * \\
(0.02)\end{array}$ & $\begin{array}{c}-0.004 \\
(0.88)\end{array}$ & $\begin{array}{l}0.007 \\
(0.36)\end{array}$ & $\begin{array}{c}-0.091 * * * \\
(0.00)\end{array}$ \\
\hline $\begin{array}{c}\text { Discretionary } \\
\text { accruals } \\
\text { changes }\end{array}$ & Mean & $\begin{array}{c}0.018 * * \\
(0.04)\end{array}$ & $\begin{array}{c}-0.052 * \\
(0.06)\end{array}$ & $\begin{array}{l}0.009 \\
(0.45)\end{array}$ & $\begin{array}{c}0.023 * \\
(0.06)\end{array}$ & $\begin{array}{c}-0.089 * * * \\
(0.00)\end{array}$ \\
\hline $\begin{array}{l}\text { before and } \\
\text { after the } \\
\text { switch }\end{array}$ & Median & $\begin{array}{c}0.011 * * \\
(0.04)\end{array}$ & $\begin{array}{c}-0.053 * * \\
(0.01)\end{array}$ & $\begin{array}{c}-0.002 \\
(0.60)\end{array}$ & $\begin{array}{c}0.007 * \\
(0.06)\end{array}$ & $\begin{array}{c}-0.054 * * * \\
(0.00)\end{array}$ \\
\hline
\end{tabular}

Notes:

(1) Numbers in parentheses correspond with the $p$ values of the $T$-test of means and of median signed rank test (null hypothesis $\mu=0$ ). Numbers in the last column of the table are results of $T$ test of paired samples and of Wilcoxon signed rank test. *, **, *** mean the means or medians are significant at 10\%,5\%,1\% levels respectively (two tailed test).

(2) We deleted from our samples companies which had involuntarily changed their auditors, resulting in a smaller sample (165 companies) during the same period from 1999-2002, as compared with Chen and Zhang's 183 sample companies.

\subsection{Effects of auditor switch on auditor independence}

As qualified professionals, auditors should be able to identify earnings manipulation behaviors and disclose such behaviors by giving modified audit opinions. When a listed company manipulated its earnings by changing incumbent auditor and the successive auditor detected it and threw daylight on the company's earnings manipulation behaviors by giving modified opinions, we 
believed that the independence of the successive auditor had not been impaired. On the contrary, if successive auditor made concessions to his/her client and presented standard opinions accordingly, we regarded the situation as auditor independence being damaged. In addition, companies received modified opinions might change auditors in hope of getting better opinions, rather than for the purpose of earnings manipulation. In view of these possibilities, we divided sample companies into sub-groups in accordance with types of the auditor opinions they had received and compared respectively effect of the types of opinions on discretionary accruals, as shown in Table 3. Considering the sample of loss-suffering companies (34 companies in total) was quite small, we did not analyze separately effects of previous different audit opinions on their discretionary accruals.

Table 3 Effects of audit opinions both before and after auditor switch on discretionary accruals

\begin{tabular}{|c|c|c|c|c|c|c|}
\hline \multirow[t]{3}{*}{ Year } & \multicolumn{4}{|c|}{ Profit-making companies } & \multirow{2}{*}{\multicolumn{2}{|c|}{$\begin{array}{l}\text { Loss-suffering } \\
\text { companies } \\
\text { (types of audit } \\
\text { opinion received in } \\
\text { the previous year } \\
\text { not distinguished) }\end{array}$}} \\
\hline & \multicolumn{2}{|c|}{$\begin{array}{l}\text { Received standard } \\
\text { opinions in the } \\
\text { previous year }\end{array}$} & \multicolumn{2}{|c|}{$\begin{array}{l}\text { Received } \\
\text { modified } \\
\text { opinions in the } \\
\text { previous year }\end{array}$} & & \\
\hline & Mean & Median & Mean & Median & Mean & Median \\
\hline $\begin{array}{l}\text { Received } \\
\text { standard } \\
\text { opinions in the } \\
\text { current year }\end{array}$ & \multicolumn{2}{|c|}{ (1) $n=183$} & \multicolumn{2}{|c|}{ (2) $n=30$} & \multicolumn{2}{|c|}{ (3) $n=19$} \\
\hline $\begin{array}{l}\text { Year before the } \\
\text { switch }\end{array}$ & $\begin{array}{l}-0.013^{*} \\
(0.07)\end{array}$ & $\begin{array}{l}-0.015^{* * *} \\
(0.00)\end{array}$ & $\begin{array}{c}-0.014 \\
(0.39)\end{array}$ & $\begin{array}{c}-0.025^{*} \\
(0.10)\end{array}$ & $\begin{array}{r}0.003 \\
(0.92)\end{array}$ & $\begin{array}{c}0.008 \\
(1.00)\end{array}$ \\
\hline $\begin{array}{l}\text { Year of the } \\
\text { switch }\end{array}$ & $\begin{array}{r}0.005 \\
(0.50)\end{array}$ & $\begin{array}{r}0.007 \\
(0.55)\end{array}$ & $\begin{array}{r}-0.003 \\
(0.84)\end{array}$ & $\begin{array}{c}-0.003 \\
(0.59)\end{array}$ & $\begin{array}{l}-0.069^{* *} \\
(0.02)\end{array}$ & $\begin{array}{l}-0.081 \\
(0.36)\end{array}$ \\
\hline $\begin{array}{l}\text { Discretionary } \\
\text { accruals } \\
\text { changes before } \\
\text { and after the } \\
\text { switch }\end{array}$ & $\begin{array}{l}0.018^{*} \\
(0.08)\end{array}$ & $\begin{array}{l}0.011^{* *} \\
(0.04)\end{array}$ & $\begin{array}{r}0.011 \\
(0.63)\end{array}$ & $\begin{array}{r}0.006 \\
(0.61)\end{array}$ & $\begin{array}{c}-0.072 * \\
(0.07)\end{array}$ & $\begin{array}{l}-0.057^{*} \\
(0.06)\end{array}$ \\
\hline $\begin{array}{l}\text { Received } \\
\text { modified } \\
\text { opinions in the } \\
\text { current year }\end{array}$ & \multicolumn{2}{|c|}{ (4) $n=16$} & \multicolumn{2}{|c|}{ (5) $n=20$} & \multicolumn{2}{|c|}{ (6) $n=15$} \\
\hline $\begin{array}{l}\text { Year before the } \\
\text { switch }\end{array}$ & $\begin{array}{r}0.023 \\
(0.44)\end{array}$ & $\begin{array}{l}0.032 * \\
(0.08)\end{array}$ & $\begin{array}{r}-0.026 \\
(0.23)\end{array}$ & $\begin{array}{l}-0.018 \\
(0.26)\end{array}$ & $\begin{array}{r}-0.027 \\
(0.45)\end{array}$ & $\begin{array}{r}0.025 \\
(1.00)\end{array}$ \\
\hline $\begin{array}{l}\text { Year of the } \\
\text { switch }\end{array}$ & $\begin{array}{r}0.027 \\
(0.34)\end{array}$ & $\begin{array}{r}0.017 \\
(0.80)\end{array}$ & $\begin{array}{r}0.009 \\
(0.60)\end{array}$ & $\begin{array}{c}0.016 \\
(0.26)\end{array}$ & $\begin{array}{l}-0.054 * * \\
(0.02)\end{array}$ & $\begin{array}{l}-0.078^{* *} \\
(0.04)\end{array}$ \\
\hline
\end{tabular}




\begin{tabular}{|c|c|c|c|c|c|c|}
\hline \multirow{3}{*}{ Year } & \multicolumn{4}{|c|}{ Profit-making companies } & \multirow{2}{*}{\multicolumn{2}{|c|}{$\begin{array}{l}\text { Loss-suffering } \\
\text { companies } \\
\text { (types of audit } \\
\text { opinion received in } \\
\text { the previous year not } \\
\text { distinguished) }\end{array}$}} \\
\hline & \multicolumn{2}{|c|}{$\begin{array}{l}\text { Received standard } \\
\text { opinions in the } \\
\text { previous year }\end{array}$} & \multicolumn{2}{|c|}{$\begin{array}{l}\text { Received modified } \\
\text { opinions in the } \\
\text { previous year }\end{array}$} & & \\
\hline & Mean & Median & Mean & Median & Mean & Median \\
\hline $\begin{array}{l}\text { Discretionary } \\
\text { accruals } \\
\text { changes } \\
\text { before and } \\
\text { after the } \\
\text { switch }\end{array}$ & $\begin{array}{c}0.004 \\
(0.92)\end{array}$ & $\begin{array}{c}-0.027 \\
(0.57)\end{array}$ & $\begin{array}{r}0.035 \\
(0.16)\end{array}$ & $\begin{array}{c}0.024 \\
(0.19)\end{array}$ & $\begin{array}{r}-0.027 \\
(0.47)\end{array}$ & $\begin{array}{c}-0.051 \\
(0.13)\end{array}$ \\
\hline
\end{tabular}

Notes: Numbers in parentheses correspond with the $p$ values of the $T$-test of means and of median signed rank test (null hypothesis $\mu=0$ ). Numbers in the last column of the table are results of $T$ test of paired samples and the $p$ values of Wilcoxon signed rank test. *,**,*** mean the means or medians are significant at 10\%,5\%,1\% levels respectively (two tailed test).

As Table 3 indicated, in type 1 and 3, most profit-making companies had received standard opinions before auditor switch, yet their discretionary accruals boosted up after the switch. In contrast, most loss-suffering companies significantly decreased their discretionary accruals after the switch. Since both profit-making companies and loss-suffering companies had received no unfavorable opinions after auditor switch, we inferred that, as compared with predecessor auditors, the successive auditors in these companies failed to exercise necessary prudence against earnings management behaviors.

Secondly, among the 50 companies received modified opinions in the previous year, their discretionary accruals increased insignificantly. After auditor switch, 30 companies $(60 \%)$ obtained standard opinions, 5 companies $(10 \%)$ received better type of opinions ${ }^{6}$, indicating that motives behind the auditor switch behaviors of those companies are mostly for audit opinion improvement, rather than for earnings manipulation.

Also, we found that whether a company receives unfavorable opinion after auditor switch has nothing to do with changes in its discretionary accruals. To confirm, we studied the audit reports of 51 listed companies which had received modified opinions from successive auditors (among these modified opinions, 39 were unqualified with explanatory paragraph). Results showed most companies received modified opinions due to reasons such as capital occupation, provision of guarantee for others, or inability to pay overdue loan, further indicating that

\footnotetext{
${ }^{6}$ We listed types of audit opinions, from best to worst, as below: unqualified opinion, unqualified with explanatory paragraph, qualified opinion, and adverse opinion or disclaimer of opinion.
} 
the successive auditors lacked necessary prudence against these companies' earning manipulation activities. This phenomenon, as such, reflected a successive auditor's consciousness of possible auditing risks and his/her coping measures against changes in auditing regulatory systems. For example, in recent years, the China Security Regulatory Commission (CSRC) has strengthened its supervision over cases of capital occupation by big shareholders and regulation-violating guarantees. ${ }^{7}$ Meanwhile, the number of lawsuits accusing auditors of scrimshanking has increased gradually, compelling auditors to watch closely their clients' sustainable development abilities and problem of appropriation of big shareholders.

Taken together, we found no large scale evidence showing that successive auditors, generally speaking, retain high level of conservatism for earnings manipulation behaviors. On the contrary, a majority of successive auditors present modified opinions out of considerations for operating risks or apprehension of regulation changes. We also found that although most previous modified-opinion companies did not significantly increase their discretionary accruals after auditor switch, the new opinions they received were improved to certain degrees. Hence our results indicated that auditor switch impaired the independence of successive auditors.

\subsection{Stability test}

(1) Around 2001, China's accounting standards and regulatory policies experienced great changes. In 1999, the Ministry of Finance issued Supplementary Regulations on Accounting Treatments in the Accounting System for Stock Companies, in which listed companies are required to make provisions for four depreciation reserves in accordance with relevant regulations in the Limited Liability Company Accounting System (1998). Before long, the Enterprise Accounting System (2001) extended the number of depreciation reserves from 4 to 8 . To avoid the influence of institutional factors ${ }^{8}$, we collected data from 2002 to 2004 and conducted a stability test. As expected, the results of the re-test were in line with our above conclusions (due to space limitation,

\footnotetext{
${ }^{7}$ For example, CSRC and the State-Owned Assets Supervision and Administration Commission jointly issued the Notice on Issues Relating to Related Party Transactions and Guarantees by Publicly Traded Companies (CSRC, 2003. No. 56), requiring certified public accountants issue special statements on possible capital occupation problems by controlling shareholders or other related parties.

${ }^{8}$ Quite a few studies reported that some listed companies took the chance of accounting system changes and took big baths. These companies made huge amount of provisions for depreciation to digest their non-performing assets of the previous years or create favorable conditions for future profit making (e.g. Huang, 2002, Dai et, al, 2005).
} 
detailed stability test results were not presented in the present article).

(2) As noted, when estimating discretionary accruals, we omitted observation values of companies with extreme financial performances to reduce or avoid estimate errors (Dechow et al., 1995). This treatment, however, might threat the stability of our conclusions. To over this weakness, we re-estimated the discretionary accruals of sample companies without deleting the extremes. We found that, much to our delight, the results of re-test was consistent with the former conclusions. What needs to be clarified is that, after deleting the extremes, the degrees of fitness of both the Jones model and its modified model were improved as a whole. Thus the estimated values of discretionary accruals were more accurate. It seemed reasonable to exclude extremes in the calculation of estimated values of discretionary accruals.

(3) After dividing sample companies into sub-groups such as profit making or losing companies, and companies with/without auditor opinions changes after the switch, we compared differences in discretionary accruals between companies changed their auditors and companies did not. In line with our above conclusions, the results showed that companies with auditor switches tend to have greater and more significant changes in discretionary accruals. This may partially explain the increasingly frequent cases of auditor switches among listed companies after 2001: a more rigorous institutional environment escalate the long-existed conflicts between listed companies and their auditors, tempting the former to change their less-cooperative incumbent auditors in hopes of finding more "desirable" successor auditors.

\section{Further analysis}

As noted, listed companies can manipulate their earnings by auditor switch. However, we were more interested in finding out the specific methods these companies had used to successfully manipulate earnings. In doing so, we proceeded to analyze the specific items of earnings manipulation and their effects on a company's net profit. We studied the account title of "indirect calculation of operating cash flow" in sample listed companies' cash flow statements and identified the items of discretionary accruals. What needs to be notified is that though relevant data in CSMAR started as early as 2000, out of consideration for changes in calculation methods of accrued items after $2001^{9}$, we only chose 179

\footnotetext{
${ }^{9}$ The Enterprise Accounting System (2001) required that enterprises add four new provisions for reserves, resulting in changes in calculation methods for accrued items. Likewise, this situation also happened in 1999 when the Supplementary Regulations on Accounting Treatments in the Accounting System for Stock Companies was issued.
} 
auditor-switching companies from 2002-2004 (actual data collection period was from 2001-2004) as samples. Specifically,

(1) We standardized all accrued items in accordance with a company's total assets of the previous year. Thus the degree of effect a certain accrued item on profit equaled its effects on the profit margin of total assets (net profit/total asses at the end of the previous year) in the present article.

(2) Drawing on extant literature, we identified three items of accrued profit vulnerable to earnings manipulation, namely depreciation reserves (contained provisions for asset depreciation), amortization and provisions (included amortization and provisions for intangible assets, prepaid expense and accrued expense), and non-recurring profit and loss (insisted of a number of non-recurring items such as asset disposal or investment income, etc).

(3) Particularly, as the indirect method for cash flow statement was calculated according to the equation of "net profit + accruals = net cash flow from operating", we inversely marked all accruals from the data bank to accord with the definitions of accruals in this article.

Table 4 Effects of auditor switch on listed companies' net profit from 2002 to 2004

\begin{tabular}{|c|c|c|c|c|}
\hline $\begin{array}{l}\text { Types of } \\
\text { accrued profit }\end{array}$ & $\begin{array}{l}(1) \\
\text { Depreciation } \\
\text { reserves }\end{array}$ & $\begin{array}{l}(2) \\
\text { Amortization } \\
\text { and provisions }\end{array}$ & $\begin{array}{l}\text { ( } 3 \text { ) } \\
\text { Non-recurring } \\
\text { profit and loss }\end{array}$ & $\begin{array}{c}\text { (4) } \\
\text { Comprehensive }\end{array}$ \\
\hline \multicolumn{5}{|c|}{ Panel A: All auditor-switching companies, $n=179$} \\
\hline $\begin{array}{l}\text { Year before the } \\
\text { switch }\end{array}$ & $\begin{array}{l}-0.008^{* * *} \\
(0.00)\end{array}$ & $\begin{array}{l}-0.005 * * * \\
(0.00)\end{array}$ & $\begin{array}{l}0.002 * * \\
(0.05)\end{array}$ & $\begin{array}{l}-0.01 * * * \\
(0.00)\end{array}$ \\
\hline Year of the switch & $\begin{array}{l}-0.005^{* * *} \\
(0.00)\end{array}$ & $\begin{array}{l}-0.004 * * * \\
(0.00)\end{array}$ & $\begin{array}{l}0.005^{* * *} \\
(0.00)\end{array}$ & $\begin{array}{l}-0.003 \\
(0.13)\end{array}$ \\
\hline $\begin{array}{l}\text { Discretionary } \\
\text { accruals changes } \\
\text { before and after } \\
\text { the switch }\end{array}$ & $\begin{array}{l}0.003 * \\
(0.10)\end{array}$ & $\begin{array}{r}0.001 \\
(0.11)\end{array}$ & $\begin{array}{r}0.003 \\
(0.11)\end{array}$ & $\begin{array}{l}0.007^{* *} \\
(0.02)\end{array}$ \\
\hline \multicolumn{5}{|c|}{ Panel B: Companies reporting profit at the year of auditor switch $\quad(R O E>0), n=159$} \\
\hline $\begin{array}{l}\text { Year before the } \\
\text { switch }\end{array}$ & $\begin{array}{l}-0.007 * * * \\
(0.00)\end{array}$ & $\begin{array}{l}-0.005 * * * \\
(0.00)\end{array}$ & $\begin{array}{l}0.002 * * \\
(0.04)\end{array}$ & $\begin{array}{l}-0.01 * * * \\
(0.00)\end{array}$ \\
\hline Year of the switch & $\begin{array}{l}-0.002 * * * \\
(0.00)\end{array}$ & $\begin{array}{l}-0.004 * * * \\
(0.00)\end{array}$ & $\begin{array}{l}0.007 * * * \\
(0.00)\end{array}$ & $\begin{array}{r}0.001 \\
(0.71)\end{array}$ \\
\hline $\begin{array}{l}\text { Discretionary } \\
\text { accruals changes } \\
\text { before and after } \\
\text { the switch }\end{array}$ & $\begin{array}{l}0.005^{* *} \\
(0.01)\end{array}$ & $\begin{array}{r}0.001 \\
(0.24)\end{array}$ & $\begin{array}{l}0.005^{* *} \\
(0.02)\end{array}$ & $\begin{array}{l}0.011^{* * * *} \\
(0.00)\end{array}$ \\
\hline
\end{tabular}




\begin{tabular}{|c|c|c|c|c|}
\hline & & & & (Continued) \\
\hline $\begin{array}{l}\text { Types of } \\
\text { accrued profit }\end{array}$ & $\begin{array}{c}(1) \\
\text { Depreciation } \\
\text { reserves }\end{array}$ & $\begin{array}{c}\text { (2) } \\
\text { Amortization } \\
\text { and provisions }\end{array}$ & $\begin{array}{l}\text { ( } 3 \text { ) } \\
\text { Non-recurring } \\
\text { profit and loss }\end{array}$ & $\begin{array}{c}\text { (4) } \\
\text { Comprehensive }\end{array}$ \\
\hline \multicolumn{4}{|c|}{ Panel C: Companies reporting loss at the year of auditor switch $(R O E<0)$, } & $n=20$ \\
\hline $\begin{array}{l}\text { Year before the } \\
\text { switch }\end{array}$ & $\begin{array}{l}-0.016^{* * *} \\
(0.01)\end{array}$ & $\begin{array}{l}-0.004 * * * \\
(0.001)\end{array}$ & $\begin{array}{r}0.004 \\
(0.54)\end{array}$ & $\begin{array}{r}-0.017 \\
(0.11)\end{array}$ \\
\hline Year of the switch & $\begin{array}{l}-0.027 * * * \\
(0.00)\end{array}$ & $\begin{array}{l}-0.002 * * * \\
(0.226)\end{array}$ & $\begin{array}{l}-0.006 * * * \\
(0.00)\end{array}$ & $\begin{array}{l}-0.035^{* * * *} \\
(0.00)\end{array}$ \\
\hline $\begin{array}{l}\text { Discretionary } \\
\text { accruals changes } \\
\text { before and after } \\
\text { the switch }\end{array}$ & $\begin{array}{l}-0.011 * \\
(0.07)\end{array}$ & $\begin{array}{c}0.002 \\
(0.103)\end{array}$ & $\begin{array}{l}-0.01 \\
(0.17)\end{array}$ & $\begin{array}{l}-0.018 * \\
(0.10)\end{array}$ \\
\hline
\end{tabular}

Notes:

(1) All items in the table are adjusted according to the total assets of the previous year. Type 4 "comprehensive" is the sum of the first three types of accrued profits.

(2) Numbers in the parentheses correspond with the $p$ values of the $T$-test of means (null hypothesis $\mu=0)$. *, **, *** mean the means are significant at $10 \%, 5 \%, 1 \%$ levels respectively.

Panel A demonstrated that, as a whole, listed companies boosted their earnings mainly by reducing depreciation reserves (contributing to $0.3 \%$ of profit gain) and by increasing non-recurring profits (contributing to $0.3 \%$ of profit gain). The reasons are as follows: first, there are no rigid regulations of provision for assets depreciation, thus comparatively speaking, listed companies can manipulate this type of accruals easier; secondly, Chinese listed companies frequently involve into abnormal transactions such as stock ownership transfer assets sales or replacement among related parties, etc. As a result, listed companies are prone to adjust their earnings with these items. Table 4 also shows that some listed companies utilized amortization of prepaid or accrued expense to adjust their earnings. In all, after auditor switch, listed companies increased their accruals by $0.7 \%$ with the above three means.

We mentioned earlier that profit-making companies and loss-suffering companies tend to manipulate their earnings along different directions. Consistent with our findings, Panel B indicates that profit-making companies, if ever, are more likely to increase their earnings by reducing depreciation reserves or by increasing non-recurring profits. Taken together, their earnings increased by $1.1 \%(p=0.001)$. By this way. Contrarily, loss-suffering companies have strong motives for "big bathes". Panel C indicates that loss-suffering companies, if ever, are more likely to reduce their reported earnings by increasing depreciation reserves and by increasing non-recurring losses. Taken together, their earnings decreased by $1.8 \%(p=0.097)$. These results strongly supported our hypothesis, that is, firms reporting profit in the year of auditor change would significantly 
increase their discretionary accruals after auditor switch, while firms reporting loss in the year of auditor change would remarkably decrease their discretionary accruals after auditor switch. Due to sample limitation, we did not make detailed comparison between companies with auditor opinions changes after the switch and companies without.

\section{Conclusion and limitations}

This article empirically tests the relation among auditor switch, earnings manipulation and auditor independence. The results showed that (1) for companies reporting profit in the year of auditor change, their formerly negative discretionary accruals tend to boost up after the switch. As a rule, these companies fulfill their purposes of earnings rise by means of reducing asset depreciation reserves and increasing non-recurring losses; (2) in contrast, companies reporting loss in the year of auditor change had strong motives for "big bath"; (3) we failed to find large-scale evidence to show that successive auditors hold more prudent attitudes towards earning manipulation behaviors. On the contrary, we found that there was a tendency of decrease in successive auditors' conservatism. The results indicated that auditor switch is related to the conservatism of the predecessor auditor and behavior of auditor switching impairs the independence of successive auditors. We thus suggest that government regulators need to take necessary measures to restrain listed companies' arbitrariness in auditor switch and its impairment to auditor independence. In addition, in daily supervisory activities, special attentions should be drawn to profit adjustment behaviors, such as depreciation reserves increase/reduction or non-recurring profit or loss adjustment, etc. Finally, we also suggest that different supervision emphases should be laid on profit-making companies and loss-suffering companies to prevent the former from increasing earnings and the latter from reducing earnings.

This research has at least two limitations: first, a hidden premise of our research was that auditor change occurs solely because a listed company intends to do so, neglecting the fact that an auditor may unilaterally quit his/her current job. This could lead to inaccuracy in the result of our study; secondly, other factors may also affect a listed company's decision of auditor change, such as audit fee, big shareholder change, etc. Therefore, further study needs to be given to the comprehensive examination of all these factors influencing auditor switch.

Acknowledgements We appreciate the valuable comments and advices from the anonymous reviewers. 


\section{References}

Chen Wucao, Zhang Hong(2004). Earning management, auditor changing and auditor independence. Journal of Accounting Research, (8): 81-86(in Chinese)

Chen Xiao, Dai Cuiyu(2004). Empirical analysis on the earnings management of the A-share loss firms. China Accounting Review, (2): 299-310(in Chinese)

Chen Xiaoyue, Xiao Xing, Guo Xiaoyan(2000). Qualifications for rights offering and profit manipulation of listed companies. Journal of Economic Research, (1): 30-36(in Chinese)

Dai Deming, Mao Xinshu, Deng Pan(2005). Research on the asset loss provision withdrawing behavior of inferior listed firms in China. Journal of Finance and Economics, (7): 71-82(in Chinese)

De Fond M L, Wong T J, Li S(2000). The impact of improved auditor independence on audit market concentration in China. Journal of Accounting and Economics, (28): 269-305

DeAngelo, L E(1981). Auditor size and audit quality. Journal of Accounting and Economics, (3): 183-199

Dechow P M, Sloan R G, Sweeney A P(1995). Detecting earnings management. The Accouting Review, (70): 193-225

DeFond M, Subramanyam K R(1998). Auditor changes and discretionary accruals. Journal of Accounting and Economics, (25): 35-67

Geng Jianxin, Yang He(2001). Analysis of changing CPA firms by listed companies. Journal of Accounting Research, (4): 57-62(in Chinese)

Haw I M, Qi D, Wu W, Zhang W(1998). Earnings management of listed firms in response to security regulations in china's emerging capital market. Chinese University of Hong Kong: working paper

Huang Shizhong(2002). Big-bath charges and its information signaling: Comparative study on Sino-U.S. typical cases. Journal of Accounting Research, (8): 10-21(in Chinese)

Lennox C(2000). Do companies successfully engage in opinion-shopping? Evidence from the UK. Journal of Accounting and Economics, (29): 321-337

Li Dongping, Huang Dehua, Wang Zhenlin(2001). Non-clean audit opinions, earnings management and CPA firms' change. Journal of Accounting Research, (6): 51-57(in Chinese)

Li Weian, Wang Xinhan, Wang Wei(2004). Earnings management and audit opinions: an empirical study based on non-operating earnings. Journal of Finance and Economics, (11): 126-135(in Chinese)

Lu Jianqiao(1999). Empirical research on earnings management of loss firms in China. Journal of Accounting Research, (9): 25-35(in Chinese)

$\mathrm{Lu}$ Yujian(2002). Empirical research on rights issue polices and earnings management behaviors of listed companies. Social Sciences in Nanjing, (3): 26-32(in Chinese)

Sun Zheng, Wang Yuetang(1999). Empirical research on resource allocation and earnings management. Journal of Finance and Economic Research, (4): 3-11(in Chinese)

Wu Liansheng, Tang Li(2005). Auditor-switching decision and the improvement of audit opinions. Journal of Audit Research, (2): 34-40(in Chinese)

Yang He, Xu Peng(2004). An empirical study on the effects of auditor switches on audit independence in China. Journal of Audit Research, (1): 83-88(in Chinese)

Zhang Yongkui, Liu Feng(2002). An empirical study on the correlation between earnings management and auditing opinion. China Accounting and Finance Review, (4): 1-22(in Chinese) 